\title{
THE PRESENCE OF MINERALS IN CLEAR ORANGE JUICES
}

Saša R. Savić*, Sanja M. Petrović, Jovana J. Stamenković, Živomir B. Petronijević

(ORIGINAL SCIENTIFIC PAPER)

UDC 663.81:549.08

Faculty of Technology, University of Niš, Leskovac, Serbia

Fruit juice is the product obtained by mechanical processing of one or more types of technologically ripe, fresh, chilled or frozen fruit, which is not but can be fermented, the taste, color and aroma of which must be specific to the type of fruit from which the fruit juice is produced. Fruit juices are important in the human diet since they contain different nutrients, especially vitamins, minerals and carbohydrates. In this paper the content of $\mathrm{Ag}, \mathrm{Al}, \mathrm{B}, \mathrm{Ca}, \mathrm{Cd}$, Co, Cr, Cu, Fe, K, Li, Mg, Mn, Na, Ni, Pb, Sr, $\mathrm{Zn}, \mathrm{Si}, \mathrm{As}, \mathrm{P}, \mathrm{Mo}$ and $\mathrm{Sb}$ in clear orange juices found the local market on the territory of Leskovac was investigated. The preparation of the samples was done by wet digestion. The concentrations of elements after digestion were determined by Inductively Coupled Plasma - Optical Emission Spectrometry (ICP-OES). Based on the obtained results it can be concluded that all investigated samples of clear orange juices do not have the required level of potassium and phosphorus. On the other side, due to high levels of molybdenum and arsenic, the consumption of clear orange juices in higher amounts could lead to a greater intake of these elements and potentially unwanted adverse effects.

Keywords: Minerals, Clear orange juice, ICP-OES

\section{Introduction}

It is widely known that fruit represents a good source of vitamin $\mathrm{C}$, carotenoids, minerals (especially $\mathrm{Mg}$ and $\mathrm{K}$ ), as well as various kinds of antioxidants and dietary fiber (pectin). All these compounds possess a protective effect against degenerative and chronic diseases such as cancer and cardiovascular diseases [1-3]. Therefore, high consumption of fruit products is highly recommended. Generally, the beneficial effects of fruits and their products depend on the amount consumed in a daily diet, the type of fruit and the content of biologically active compounds [3]. Also, it is well known that some functional compounds are present not only in fruits but also in fruit products like juices.

Fruit juice is a product obtained by a mechanical process of one or more technologically mature, fresh, chilled or frozen fruits, which are not fermented but can be fermented and the taste, color and aroma of which must be specific to the type of fruit from which the juice is produced [4]. Depending on the water content of the juice, fruit juices can be divided into concentrated fruit juice, fruit powder juice and fruit nectar $[4,5]$.

Fruit juices are important for a human diet since they contain different nutrients, vitamins, and especially minerals $[6,7]$. It is known that metal ions regulate a wide range of physiological mechanisms with significant specificity and selectivity, primarily as components of enzymes and other molecular complexes. The reactivity of the complex depends both on specific characteristics of the corresponding protein, and hence the flexibility, as well as on the properties of the metal [8]

Potassium is known as the most abundant intracellular ion that it is very important for the membrane transport, energy metabolism and normal functioning of the cells. It plays an important role in the transmission of nerve impulses and muscle contractions. Potassium is also necessary for the regulation of blood pressure and water balance in the body. There is evidence that a diet rich in potassium can reduce the risk of high blood pressure and a stroke [9]. Sodium is the part of the living bicarbonate buffer system and has influence on the distribution of water through osmosis, as well as the acid-base balance in blood. In addition, it is necessary for neuromuscular function because it takes part in the transport of glucose and other nutrients [5]. Calcium salts provide bones rigidity while calcium ions play an important role in many metabolic processes. Also, there is a steady flow of this element along the cell membrane and many neuromuscular and other cellular functions depend on the calcium ions concentration in the extracellular fluid [9]. Iron is included in erythrocytes through the structure of hemoglobin which consists of four subunits, whereby each containing a heme group and a single protein chain. Also, it is known that $10 \%$ of iron which is present in the body is used for the activity of some enzymes that generate energy $[5,10,11]$. Taken orally or topically applied in the form of cream, zinc can reduce the production of fat and it may be effective in the acne control, as well as the creation of new and the existing acnes. Zinc can act as: anti-arthritic,

\footnotetext{
*Author address: Saša Savić, Faculty of Technology, University of Niš, Bulevar Oslobodjenja 124, 16000

Leskovac, Serbia

E-mail: sasa.savic@tf.ni.ac.rs

The manuscript received: April, 09, 2015

Paper accepted: November, 11, 2015.
} 
anti-infective, antiviral, astringent, immunostimulating or healing agent $[12,13]$. Copper is an essential metal in the human body, animals and plants. In the nature, it appears in the form of element or mineral. Copper is essential for the hemoglobin production and it is an essential ingredient in a large number of enzymes, so the lack of copper in the body leads to serious disorders and anemia [14].

Although fruit juices are highly appreciated tasty food that usually have exceptional nutritional qualities, in some cases they can be a potential source of toxic elements because of their accumulative effect, or can lead to nutritional problems due to low concentrations of essential elements [6]. The quality of fruit products is diminished with increasing the concentration of toxic compounds, environmental pollutants (especially pesticides), polychlorinated biphenols (PCB's) and heavy metals, especially $\mathrm{Pb}$ and $\mathrm{Cd}$. Some compounds presented in the juices have been identified as mutagenic or carcinogenic [6,14-19]. The carcinogenic or genotoxic effects may be mediated by the interaction of juice components with transition metals or with autooxidation sub-products [18-20]. Bearing in mind all these states, as well as wide consumption of fruit juices, it is very important to evaluate industrial fruit juices for the consumer safety. The content of silver, aluminum, arsenic, boron, calcium, cadmium, cobalt, chromium, copper, iron, potassium, lithium, magnesium, sodium, nickel, lead, strontium, zinc, silicon, arsenic, phosphorus, molybdenum and antimony in clear orange juices that are found in the local market on the territory of Leskovac is determined in this work by optical emission spectrometry with inductively coupled plasma as a source of excitation (ICP-OES).

\section{Experimental}

\section{Reagents and standard solutions}

Distilled water, purchased from Fisher Chemical (HPLC grade) was used for orange juice dilution. The carrier gas was Argon 5.0 (99.999\% purity). In addition, the calibration standards were prepared for the above samples analysis. Multistandard IV - standard solution (Merck) containing Ag, $\mathrm{Al}, \mathrm{B}, \mathrm{Ca}, \mathrm{Cd}, \mathrm{Co}, \mathrm{Cr}, \mathrm{Cu}, \mathrm{Fe}, \mathrm{K}, \mathrm{Li}, \mathrm{Mg}, \mathrm{Mn}, \mathrm{Na}, \mathrm{Ni}, \mathrm{Pb}$, $\mathrm{Sr}, \mathrm{Zn}$, as well as additional standard solutions of $\mathrm{Si}, \mathrm{As}$, $\mathrm{P}, \mathrm{Sb}$, and Mo (Reagecon, Ireland) at the concentration of 1000 ppm were used for the preparation of calibration solutions. The preparation of standard solutions was performed by diluting standard solutions, so that the concentrations of standards for the calibration chart were in the range of expected test elements concentrations. Table 1 shows the detection wavelength for each element in the samples, correlation coefficient $\left(R^{2}\right)$, limit of detection (LOD), as well as the range of linearity.

\section{Sampling and sample preparation}

Seven orange juice samples produced by different manufacturers were taken in November 2014 in the local market on the territory of Leskovac. The preparation of the samples was carried out by wet digestion. $2 \mathrm{ml}$ of the orange juice sample was mixed with $18 \mathrm{ml}$ of $2 \%$ nitric acid.
After $24 \mathrm{~h}$, all samples were diluted with distilled water purified by Fisher Chemical (HPLC grade) and filtered before ICP-OES analysis.

Table 1. Calibration parameters: $\lambda$; R2; LOD and the range of linearity

\begin{tabular}{|c|c|c|c|c|}
\hline Element & $\begin{array}{c}\text { Detection } \\
\text { wavelength }(\mathrm{nm})\end{array}$ & $\begin{array}{c}\text { Correlation } \\
\text { coefficient }\left(R^{2}\right)\end{array}$ & $\begin{array}{l}\text { Limit of } \\
\text { detection } \\
(\mu \mathrm{g} / \mathrm{L})\end{array}$ & $\begin{array}{l}\text { Linearity range } \\
(\mathrm{mg} / \mathrm{L})\end{array}$ \\
\hline $\mathrm{Ag}$ & $\begin{array}{l}224.641 \\
328.068\end{array}$ & $\begin{array}{l}0.99993 \\
0.99995\end{array}$ & 0.39 & $\begin{array}{l}1.45 \times 10^{-2}-12.00 \\
3.99 \times 10^{-4}-12.00\end{array}$ \\
\hline $\mathrm{Al}$ & $\begin{array}{l}167.078 \\
394.401\end{array}$ & $\begin{array}{l}0.99985 \\
0.99998\end{array}$ & $7.6 \times 10^{-2}$ & $\begin{array}{c}7.6 \times 10^{-5}-2.40 \\
1.55 \times 10^{-3}-12.00\end{array}$ \\
\hline B & $\begin{array}{l}182.641 \\
249.773\end{array}$ & $\begin{array}{l}0.99999 \\
0.99999\end{array}$ & 6.43 & $\begin{array}{l}7.37 \times 10^{-3}-12.00 \\
6.43 \times 10^{-3}-12.00\end{array}$ \\
\hline $\mathrm{Ca}$ & $\begin{array}{l}183.801 \\
396.847\end{array}$ & $\begin{array}{l}0.99995 \\
0.99946\end{array}$ & 2.14 & $\begin{array}{c}1.6-480.00 \\
2.14 \times 10^{-3}-2.41\end{array}$ \\
\hline $\mathrm{Cd}$ & 214.438 & 0.99994 & 0.127 & $1.27 \times 10^{-4}-12.00$ \\
\hline Co & 228.616 & 0.99980 & 0.327 & $3.27 \times 10^{-4}-12.00$ \\
\hline $\mathrm{Cr}$ & 283.563 & 0.99998 & 0.435 & $4.35 \times 10^{-4}-12.00$ \\
\hline $\mathrm{Cu}$ & $\begin{array}{l}224.700 \\
324.754\end{array}$ & $\begin{array}{l}0.99999 \\
0.99999\end{array}$ & 0.259 & $\begin{array}{l}9.07 \times 10^{-4}-12.00 \\
2.59 \times 10^{-4}-12.00\end{array}$ \\
\hline $\mathrm{Fe}$ & 259.941 & 0.99997 & 0.118 & $1.18 \times 10^{-4}-12.00$ \\
\hline $\mathrm{K}$ & $\begin{array}{l}404.721 \\
766.491\end{array}$ & $\begin{array}{l}0.99998 \\
0.99999\end{array}$ & 0.378 & $\begin{array}{c}0.798-300.00 \\
3.78 \times 10^{-4}-1.20\end{array}$ \\
\hline $\mathrm{Li}$ & $\begin{array}{l}323.261 \\
670.780\end{array}$ & $\begin{array}{l}1.00000 \\
0.99997\end{array}$ & $5.75 \times 10^{-2}$ & $\begin{array}{c}7.98 \times 10^{-2}-12.00 \\
5.75 \times 10^{-5}-1.20\end{array}$ \\
\hline $\mathrm{Mg}$ & $\begin{array}{l}279.553 \\
285.213\end{array}$ & $\begin{array}{l}0.99997 \\
0.99994\end{array}$ & 0.115 & $\begin{array}{c}1.15 \times 10^{-4}-6.04 \\
4.03-120.00\end{array}$ \\
\hline $\mathrm{Mn}$ & 257.611 & 0.99992 & $3.57 \times 10^{-2}$ & $3.57 \times 10^{-5}-12.00$ \\
\hline $\mathrm{Na}$ & $\begin{array}{l}330.237 \\
598.592\end{array}$ & $\begin{array}{l}0.99994 \\
0.99989\end{array}$ & 4.75 & $\begin{array}{c}7.98-480.00 \\
4.75 \times 10^{-3}-12.00\end{array}$ \\
\hline $\mathrm{Ni}$ & 231.604 & 0.99994 & 0.474 & $4.74 \times 10^{-4}-12.00$ \\
\hline $\mathrm{Pb}$ & 220.353 & 0.99998 & 1.78 & $1.78 \times 10^{-3}-12.00$ \\
\hline $\mathrm{Sr}$ & 407.771 & 0.99998 & $6.23 \times 10^{-3}$ & $6.23 \times 10^{-6}-2.41$ \\
\hline $\mathrm{Zn}$ & 213.856 & 0.99997 & $8.2 \times 10^{-2}$ & $8.2 \times 10^{-5}-12.00$ \\
\hline $\mathrm{Si}$ & 288.158 & 0.99998 & 1.6 & $1.6 \times 10^{-3}-120$ \\
\hline As & $\begin{array}{l}189.042 \\
197.262\end{array}$ & $\begin{array}{l}0.99997 \\
0.99998\end{array}$ & $\begin{array}{l}0.88 \\
1.24\end{array}$ & $\begin{array}{l}8.8 \times 10^{-4}-12.00 \\
1.24 \times 10^{-3}-12.00\end{array}$ \\
\hline$P$ & 214.914 & 0.99992 & 3.5 & $3.5 \times 10^{-3}-240.00$ \\
\hline Mo & 204.664 & 0.99985 & 0.181 & $1.81 \times 10^{-4}-12.00$ \\
\hline $\mathrm{Sb}$ & 187.115 & 0.99992 & 2.44 & $2.44 \times 10^{-3}-12.00$ \\
\hline
\end{tabular}

\section{Analysis of samples}

The quantitative analysis of all samples was performed on ICP-OES (Inductively Coupled Plasma - Optical Emission Spectrometry, ARCOS FHE12, SPECTRO, Germany), according to the manufacturer's instructions. The instrument conditions and determined parameters are given in Table 2.

Table 2. Operating conditions for ICP-OES

\begin{tabular}{cc}
\hline Plasma Power (W) & 1500 \\
\hline Gas flow (L/min) & 13 \\
-Coolant & 0.80 \\
-Auxiliary & Cross flow \\
Nebulizer type & 0.95 \\
Nebulizer flow rate (L/min) & 30 \\
Pump speed & 0 \\
Stabilization time (s) & 3 \\
Number of probes for each & axial \\
measuring & \\
Plasma observation &
\end{tabular}

\section{Results and discussion}

In order to obtain a more complete picture of the presence of minerals in seven clear orange juices (50\% fruit content) from the local market in Leskovac, the content 
of 23 minerals were examined. The obtained results for all samples are given in Figures 1-3. All investigated minerals were classified in three groups: macro elements, microelements and toxic elements.

The results from the presence of macro elements in seven samples of clear orange juices are shown in Figure 1. Based on obtained results, it can be concluded that among the investigated macro elements $(\mathrm{K}, \mathrm{Ca}$, $\mathrm{Mg}, \mathrm{Na}$ and $\mathrm{P}$ ), the content of potassium was the highest (15.0-301.32 mg/L). High potassium content in fruit juices is not unknown, since potassium is naturally present in fruit in the form of potassium salt of tartaric acid (potassium tartarate) [20]. In addition to orange juice, researchers have also noted a higher amount of potassium than other macro elements in the juice samples from different berries [14]. Also, a high level of potassium was reported by Demir and collaborators (2015) who detected the potassium content of 1351 and 986 $\mathrm{mg} / \mathrm{L}$ in $100 \%$ orange juice and nectar, respectively [21]. Although potassium is naturally present in fruit, other compounds such as sweetening agents (acesulpham $\mathrm{K}$ ) or preservatives (potassium benzoate-E212, potassium sorbate-E201, potassium bisulfite-E228) which are added during the production, can increase the content of this macro element in fruit juices above the level obtained from the fruit itself [20]. According to WHO, the recommended daily dose of potassium is $2,000 \mathrm{mg}$ [22]. On the other side, Serbian regulations of the quality of fruit juices, concentrated fruit juices, fruit juice powder, fruit nectars and related products [4] require that the total potassium content in the orange juices is $1300-2500$ ppm. Based on the results obtained in our study, it can be concluded that all investigated samples do not have the required level of potassium.

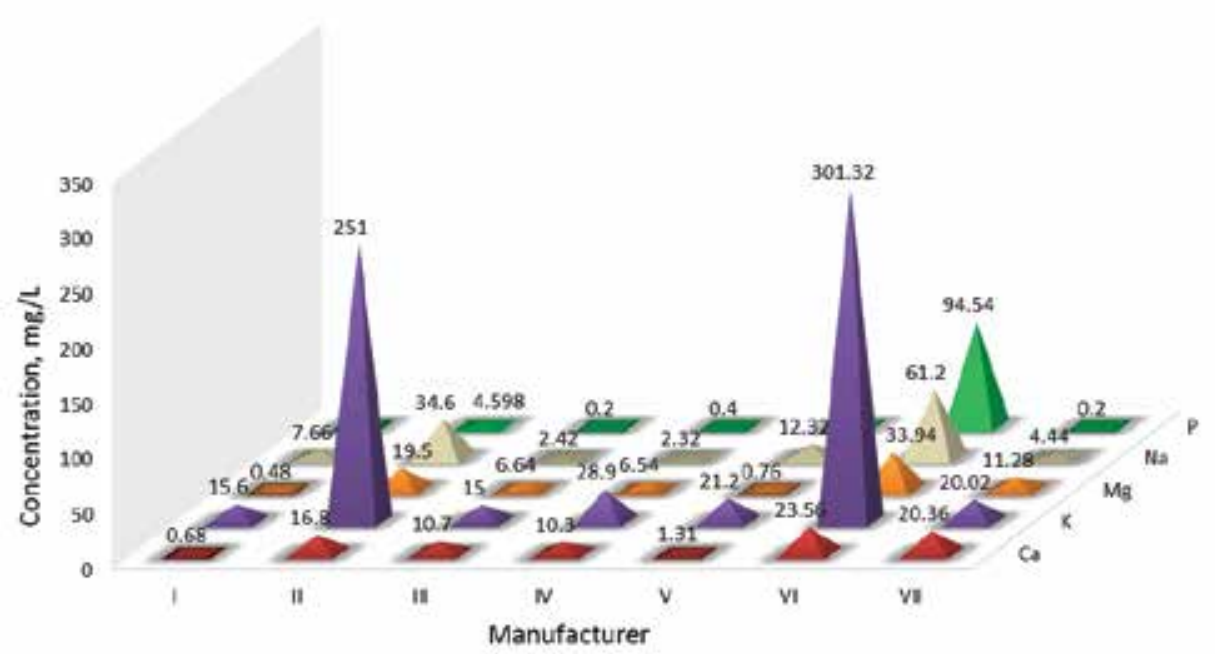

Figure 1. The presence of macro elements in clear orange juices (mg/L).

Besides potassium, a high content of sodium (2.32 to $61.2 \mathrm{mg} / \mathrm{L}$ ) was also detected in clear orange juices. By comparing the obtained results with the results reported by Tormen and collaborators (2011), where in orange juices the presence of sodium in the range of $39-40$ $\mathrm{mg} / \mathrm{L}$ was detected [20], it can be concluded that the content of sodium is similar. According to $\mathrm{WHO}$, the recommended daily dose of sodium is $500 \mathrm{mg}$ [22]. The content of calcium in the tested clear orange juices was in the range from 0.68 to $16.8 \mathrm{mg} / \mathrm{L}$. By the comparison with the results reported by Tormen and collaborators (2011) where the detected amount of calcium was $111-129$ $\mathrm{mg} / \mathrm{L}$ [20], it can be concluded that the calcium concentration in clear orange juices investigated here was pretty low. According to $\mathrm{WHO}$, the recommended daily dose of calcium is $800 \mathrm{mg}$ [22]. The lack of calcium or a negative balance of this element in the body can lead to osteoporosis, whereby it should be noted that the occurrence of this disease is not always related to the lack of calcium in the human body [9]. The presence of sodium in fruit juices usually comes from water and sodium salts such as benzoate, saccharin or citrate, while the presence of calcium and magnesium comes not just from water but also from the fruit as well. Enrichment of juices with these minerals is very simple, because their compounds (salts) are easily soluble, but on the other hand, the excessive addition of these substances can lead to salty or tart taste of juice, and therefore to the laxative effect [20]. Differences in the potassium and sodium contents were particularly evident in the juice samples made by producers IV and $\mathrm{VI}$, where potassium and sodium contents varied to about 20 and 30 times, respectively. This difference in the $\mathrm{K}$ content may be a result of different fruit quality, as well as the enlarged use of sweeteners and preservatives which contain this element. In addition, differences in the contents may also originate from 
a variety of technology and the fruit or water amount in the final product.

Magnesium, as well as previous three minerals ( $\mathrm{K}, \mathrm{Na}$ and $\mathrm{Ca}$ ), belongs to the macro elements group and its recorded concentration in clear orange juices was in the range of $0.48-33.94 \mathrm{mg} / \mathrm{L}$. The detected concentration of magnesium in the samples from our study is in accordance with the results reported by Demir and collaborators (2015) [21] where detected amounts of magnesium in $100 \%$ orange juice and nectar were 73.25 and 33.76 $\mathrm{mg} / \mathrm{L}$, respectively. Magnesium is the essential constituent which plays an important role in different vital processes in the human body. It is a component of bones, and has the influence on the nervous system and muscle activity. Magnesium deficiency can cause nervous diseases, bone deterioration and stress [5]. According to $\mathrm{WHO}$, the recommended daily dose of magnesium is in the range of $280-350 \mathrm{mg}$ [22].

Phosphorus is a very important mineral which is a primary constituent of deoxyribonucleic acid (DNA) and adenosine triphosphate (ATP). Also, phosphorus participates in the intracellular energy transfer within living cells [5]. In this study, the presence of phosphorus in the range from 0.2 to $94.54 \mathrm{mg} / \mathrm{L}$ was detected. In investigations performed by Demir and collaborators (2015) [21], the detected amounts of phosphorus in $100 \%$ orange juice and nectar were 89.27 and $51.3 \mathrm{mg} / \mathrm{L}$, respectively. According to Serbian regulations of the quality of fruit juices, concentrated fruit juices, fruit juice powder, fruit nectars and related products, the required total phosphorus content in the orange juices is $115-210 \mathrm{mg} / \mathrm{L}$ [4]. Based on this, it can be concluded that all samples investigated in this study do not meet the requirements for the phosphorus level.

From microelements group which was investigated in clear orange juices, the highest content was detected for zinc (3.3-7.16 mg/L, sample VII). The detected amount of zinc in our study was significantly higher than that reported by Krejpcio and collaborators (2005) who detected $1.177 \mathrm{mg} / \mathrm{L}$ of zinc in orange juices [3]. Similar results were reported by Tufuor and collaborators (2011) where zinc in the concentration of $0.1354 \mathrm{mg} / \mathrm{L}$ was detected [23]. Also, in their investigations Tormen and collaborators detected the presence of zinc in the range from 4.4 to $4.6 \mathrm{mg} / \mathrm{L}$ [20]. Zinc is an important component of insulin, ferments, carbohydrase, uricase and phosphatases. In biological term, zinc is very important because it is one of the trace elements and is required for normal growth [5]. According to $\mathrm{WHO}$, the recommended daily allowance of zinc is $12-15 \mathrm{mg}$ [22].

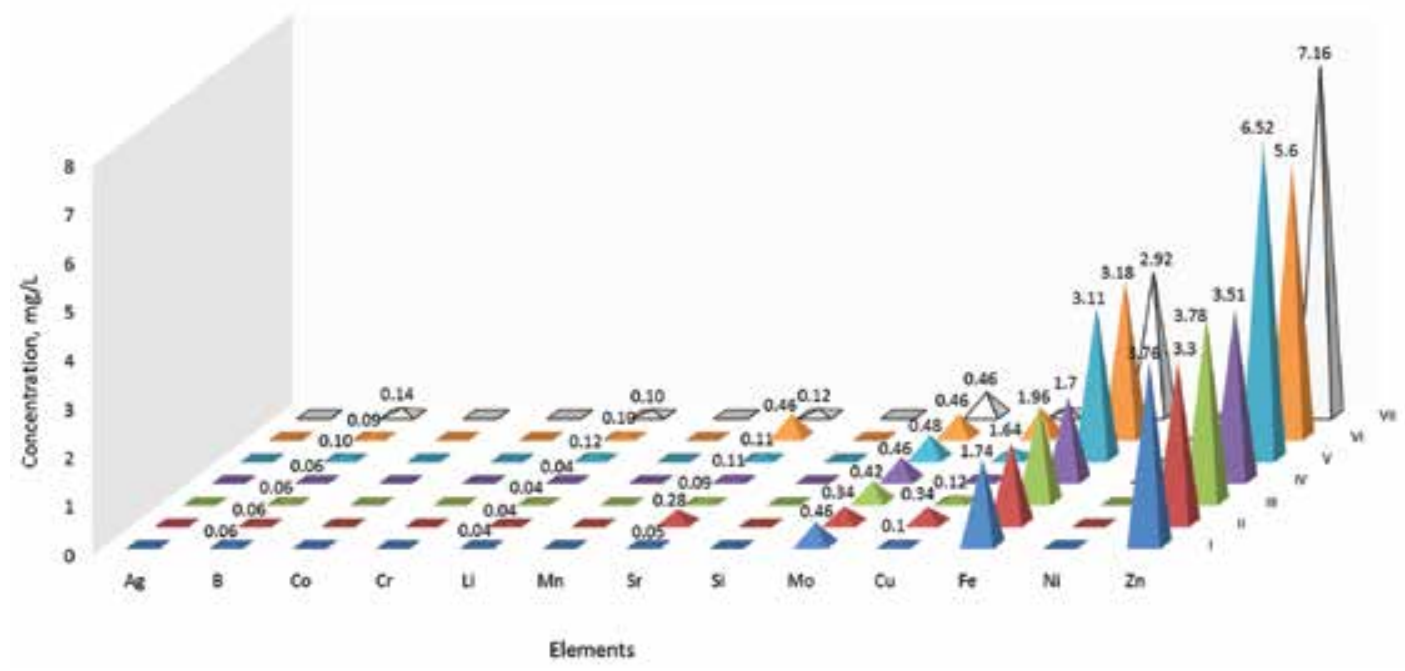

Figure 2. The presence of microelements in clear orange juices (mg/L)..

The amount of other investigated minerals in all tested orange juice samples followed the descending order $\mathrm{Fe}>\mathrm{Cu}>\mathrm{Ni}$ in all tested samples, whereby the presence of nickel was not detected. The content of iron in clear orange juices was in the range of $1.64-3.18 \mathrm{mg} / \mathrm{L}$. Compared to the previously reported results by Tufuor and collaborators (2011) where in orange juices $0.8171 \mathrm{mg} / \mathrm{L}$ of zinc was detected [23], this is a significantly higher concentration of iron. On the other side, Tormen and collaborators detected the presence of iron in the range from 9.0 to $9.6 \mathrm{mg} / \mathrm{L}$ [20]. Compared to our results, this is about a three times higher concentration of iron. The recommended iron daily dosage is $14 \mathrm{mg}[20,22]$, and its deficiency can lead to microcytic and hypochromic anemia which is characterized by the following symptoms: nausea, weakness, paleness, shortness of breath and palpitations [24].

Molybdenum enters the body through food and more than $80 \%$ of this metal is absorbed by the gastrointestinal tract. Molybdenum is an essential component of many enzymes necessary for the synthesis of urea (xanthine oxidase and xanthine dehydrogenase). In higher 
concentrations, molybdenum may result in the changes in the metabolism of nucleotides or in the decrease of the absorbance of copper [25]. In the present study, the detected amount of molybdenum was in the range of 0.34 $0.48 \mathrm{mg} / \mathrm{L}$. Tormen and collaborators (2011) reported the presence of molybdenum between $0.04-0.049 \mathrm{mg} / \mathrm{L}$ in orange juices [20]. In orange juices from Australia, as Simpkins and collaborators (2000) found, the content of molybdenum was in the range of $0.001-0.03 \mathrm{mg} / \mathrm{L}$ [26]. When compared to the results from previous studies $[20,26]$, it is evident that the presence of molybdenum in clear orange juices which we investigated was significantly higher, even to ten times. According to WHO, the dosage of molybdenum is $0.025-0.25 \mathrm{mg}$ [22]. Based on this, it can be concluded that the consumption of clear orange juices in higher amounts could lead to a greater intake of molybdenum and hence to potentially unwanted adverse effects.

The presence of lithium in the tested clear orange juices in the range of $0.04-0.12 \mathrm{mg} / \mathrm{L}$ was detected. Lithium is a trace mineral and its legitimate medical application is in the form of lithium carbonate as one of the most widely prescribed psychiatric drugs [27]. Recently, other applications of lithium e.g. in oncology, as well as in dermatology have been investigated. According to $\mathrm{WHO}$, the recommended daily dosage of lithium is $0.001-0.99$ $\mathrm{mg}$ [22].

Strontium belongs to the group of trace minerals and it has a similar biochemical pathway as $\mathrm{Ca}$ in the vertebrate body. Strontium has the role in increasing bone deposition, as well as in reducing bone resorption [28]. In our study, the detected amount of strontium was in the range of $0.05-0.46 \mathrm{mg} / \mathrm{L}$. The obtained concentration of strontium was lower when compared to the results reported by Tormen and collaborators (2011) [20] where the content of strontium in the range of $0.77-0.86 \mathrm{mg} / \mathrm{L}$ was recorded in orange juices.

The presence of boron in clear orange juices was detected in the range of $0.06-0.14 \mathrm{mg} / \mathrm{L}$. By comparing the obtained results with the results reported by Simpkins and collaborators (2000) [26] where boron was detected in the range of $0.6-2.9 \mathrm{mg} / \mathrm{L}$ in orange juices from Australia, it can be concluded that the detected amount in clear orange juices is significantly higher. Boron is present in blood in the form of free boronic acid. Many clinical studies have shown that the lack of boron may be associated with osteoporosis in menopausal women. The use of boron supplements in these patients has led to the reduction in the loss of $\mathrm{Ca}, \mathrm{Mg}$ and $\mathrm{P}$ [29]. Also, the lack of this element can lead to disorders of attention and short-term memory in humans [30]. According to WHO, the recommended daily dosage of boron is $1-3 \mathrm{mg}$ [22]. As zinc and iron, the presence of copper was also detected in all investigated orange juice samples. The detected amount of copper in samples I, III and IV was slightly higher than $0.1 \mathrm{mg} / \mathrm{L}$, while the highest amount of copper $(0.58 \mathrm{mg} / \mathrm{L})$ was detected in sample $\mathrm{VI}$. The results reported by Krejpcio and collaborators (2005) show that in orange juice copper was present in the concentration of $0.245 \mathrm{mg} / \mathrm{L}$ [3], while Tormen and collaborators (2011) reported the presence of zinc in the range from 0.14 to $0.164 \mathrm{mg} / \mathrm{L}$ [20]. Copper, along with vitamin C and zinc, helps in the maintenance of the elasticity of fibers, providing better skin structure support [5]. According to $\mathrm{WHO}$, the recommended daily dosage of copper is 1 $\mathrm{mg}$ [22]. The lack of this mineral occurs very rarely, but doctors believe that the consumption of copper supplements can be dangerous.

In addition to macro and microelements, the presence of toxic elements in clear orange juices was also investigated and the obtained results are shown in Figure 3. Aluminum is known as an extremely pro-inflammatory, pathological and genotoxic element which is particularly deleterious to the normal homeostatic operation of brain cells. But fortunately, aluminum insolubility at biological $\mathrm{pH}$ and highly effective epithelial, gastrointestinal and blood-brain barriers prevent this ubiquitous neurotoxin from accessing human biological compartments where it appears to contribute to inflammatory degeneration and pathogenic gene expression programs highly characteristic of the Alzheimer's disease (AD) [10]. In this study, the recorded amount of aluminum was in the range of $0.29-2.1 \mathrm{mg} / \mathrm{L}$. Recommended daily dosage of aluminum by WHO is $9-36 \mathrm{mg}$ [22]. The total aluminum content in fruit juice is affected by many different factors. First of all, aluminum is naturally present in the water which is used in the juice preparation. Many of additives and colors used in the production process include aluminum compounds. Also, it can be delivered through the packaging material made of aluminum [31,32]. Aluminum foil can also be damaged when it comes into the contact with the salty, sour and neutral aqueous solutions [33]. If fruit juice which is packed in carton pack reaches Al foil through the plastic and paper packaging material, it will be contaminated and potentially exposed to corrosion.

Cadmium is known as one of the most dangerous environmental pollutants. Around $6 \%$ of ingested cadmium in the body is absorbed via the gastrointestinal tract. Once adopted, cadmium binds to albumin in blood [34]. In this study, the presence of cadmium was detected in samples II, IV and VI in the concentrations of 0.02, 0.01 and $0.05 \mathrm{mg} / \mathrm{L}$, respectively. Similar results were reported by Krejpcio and collaborators (2005) where $0.01 \mathrm{mg} / \mathrm{L}$ of cadmium was detected in orange juices [3]. Unlike cadmium, the presence of lead was detected in all investigated orange juice samples. The highest amount of lead was found in sample VI (1.19 mg/L). Krejpcio and collaborators (2005) detected the presence of lead in orange jucies, in the concentration of $0.095 \mathrm{mg} / \mathrm{L}$ [3] while the detected amount of lead in investigations of Tufuor and collaborators (2011) was $0.05 \mathrm{mg} / \mathrm{L}$ [23]. The presence of lead and cadmium in juice can be the result of various factors such as water used for the preparation, the production process and the treatment of the final product. WHO has defined the so-called acceptable daily heavy metal intake which is $0.2 \mathrm{mg}$ for lead, and $0.1 \mathrm{mg}$ for 
cadmium [22]. The detected varied content of lead in the examined juice samples $(0.19-1.19 \mathrm{mg} / \mathrm{L})$ can be due to many factors. Some of the main reasons that can lead to some variations in the lead content can be the contamination of fruit or the final product with a certain amount of metal during the production process.

The presence of arsenic in all investigated samples was also detected. The concentration of arsenic in seven orange juice samples was in the range of $2.01-2.56 \mathrm{ppm}$. According to Serbian regulations on the maximum allowable residues of pesticides in food and animal feed, and the animal feed which is determined by the maximum allowable amounts of residues of the plant protection products, the allowed concentration of arsenic in fruit juices is $0.2 \mathrm{mg} / \mathrm{L}$ [35]. Based on this, it can be concluded that the presence of arsenic in orange juices is about 10 times higher than allowed. Arsenic is considered as toxic element, although there are some indications that in small amounts it could have a useful role in human health [36-38]. After absorption, arsenic is transported to the lungs and other organs and later to the skin, hair and nails where it binds to keratin [37]. Therefore, the facts that once absorbed arsenic has damaging effects in the bones, liver or kidneys [6] indicate that it is necessary to monitor and control its content.

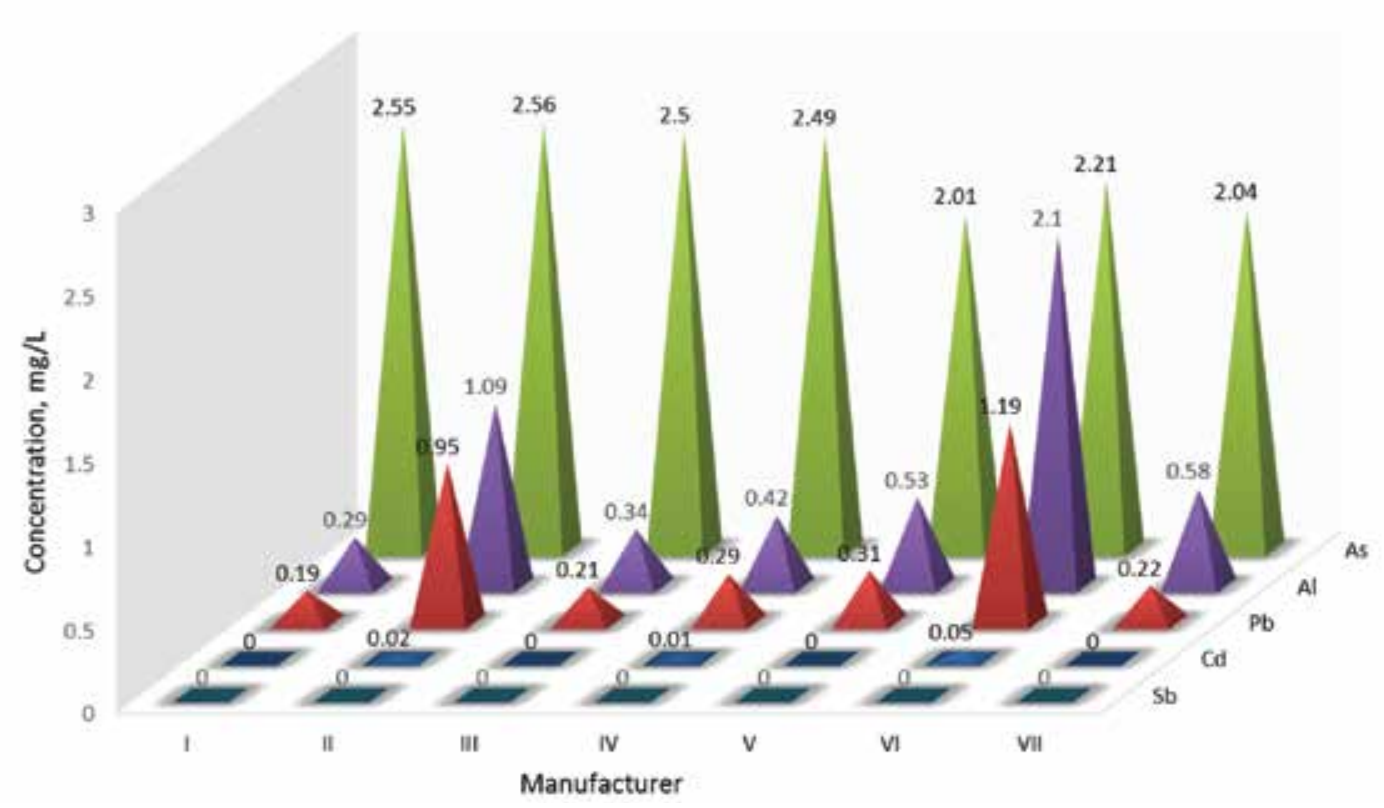

Figure 3. The presence of toxic elements in clear orange juices (mg/L).

In summary, based on the results obtained from the analyses of clear orange juices found in the markets on the territory of Leskovac, it can be concluded that all investigated samples do not contain the required level of potassium and phosphorus. In addition, the presence of calcium in clear orange juices was also low. On the other hand, due to high levels of molybdenum and arsenic, the consumption of clear orange juices in higher amounts could lead to unwanted adverse effects, and for these reasons some fruit juices obtained from orange should not be found in the market.

\section{Acknowledgements}

This work was supported by the Ministry of Education, Science and Technological Development of the Republic of Serbia under Project No.TR 34012.

\section{References}

[1] L.O. Dragsted, M. Strube, J.C. Larsen, Cancerprotective factors in fruits and vegetables: Biochemical and biological background, Pharmacology and Toxicology, 72(1) (1993) $116-135$

[2] H. Wang, G. Cao, R.L. Prior, Total antioxidant capacity of fruits, Journal of Agricultural and Food Chemistry, 44(3) (1996) $701-705$.

[3] Z. Krejpcio, S. Sionkowski, J. Bartela, Safety of Fresh Fruits and Juices Available on the Polish Market as Determined by Heavy Metal Residues, Polish Journal of Environmental Studies, 14(6) (2005) 877 - 881.

[4] Pravilnik o kvalitetu voćnih sokova, koncentrisanih voćnih sokova, voćnih sokova u prahu, voćnih nektara i srodnih proizvoda, SI. glasnik RS, br. 27/2010 od 28/04/2010.

[5] D. Velimirović, Optimizacija, validacija i primena ICP-OES metode određivanja sadržaja metala u realnim uzorcima, Doktorska disertacija, PMF, Univerzitet u Nišu, 2013.

[6] T. Hague, A. Petroczi, P.L.R. Andrews, J. Barker, D.P. 
Naughton, Determination of metal ion content of beverages and estimation of target hazard quotients: a comparative study, Chemistry Central Journal, 2(13) (2008) 1 - 9.

[7] P.R. Ashurst, Chemistry and technology of soft drinks and fruit juices, Wiley-Blackwell Publishing, 2005.

[8] S.J. Lippard, Bioinorganic chemistry: a maturing frontier, Science (New York, NY), 261(5122) (1993) 699 - 700.

[9] A. Konić-Ristić, K. Šavikin, G. Zdunić, T. Janković, Z. Juranic, N. Menković, I. Stanković, Biological activity and chemical composition of different berry juices, Food Chemistry, 125(4) (2011) 1412 - 1417.

[10] D. Velimirović, S. Mitić, S. Tosić, A. Pavlović, M. Stojković, Determination of the Content of Some Trace Elements in Particular Samples of Grains, Flours and Breads by ICPOES, Oxidation Communications, 35(1) (2013) 160 - 171.

[11] D.S. Velimirović, S.S. Mitić, S.B. Tošić, B.M. Kaličanin, A.N. Pavlović, M.N. Mitić, Levels of Major and Minor Elements in Some Commercial Fruit Juices Available in Serbia, Tropical Journal of Pharmaceutical Research October, 12(5) (2013) $805-811$.

[12] M. J. Gibney, S. A. Lanham-New, A. Cassidy, H. H. Vorster, Introduction to human nutrition: Wiley-Blackwell, New Jersey, 2009.

[13] Y. Kaymak, E. Adişen, M. Erhan, B. Çelík, M.A. Gürer, Zinc Levels in Patients with Acne Vulgaris, Journal of the Turkish Academy Dermatology, 1(3)71302a (2007) 1 - 4.

[14] P.R. Ashurst, Chemistry and technology of soft drinks and fruit juices, Wiley-Blackwell, 2008.

[15] S.I.R. Franke, K. Ckless, J.D. Silveira, G. Rubensam, M. Brendel, B. Erdtmann, J.A.P. Henriques, Study of antioxidant and mutagenic activity of different orange juices, Food Chemistry, 88 (2004) 45 - 55.

[16] B.N. Ames, Mutagenesis and carcinogenesis: endogenous and exogenous factors, Environmental and Molecular Mutagenesis, 14 (1989) $66-77$.

[17] A. Patrineli, M.N. Clifford, R. Walker, C. Ioannides, Mutagenicity of white grape juice in the Ames test, Food Chemical Toxicology, 34 (1996) 559 - 562.

[18] S.I.R. Franke, D. Prá, J. da Silva, B. Erdtmann, J.A.P. Henriques, Possible repair action of vitamin $C$ on DNA damage induced by methyl methanesulfonate, cyclophosphamide, FeSO4 and CuSO4 in mouse blood cells in vivo, Mutation Research, 583 (2005) $75-84$.

[19] S.I.R. Franke, D. Prá, R. Giulian, J.F. Dias, M.L. Yoneama, J. da Silva, B. Erdtmann, J.A.P. Henriques, Influence of orange juice in the levels and in the genotoxity of iron and cooper, Food and Chemical Toxicology, 44 (2006) 425 435.

[20] L. Tormen, D.P. Torres, I.M. Dittert, R.G.O. Araújo, V.L.A. Frescura, A.J. Curtius, Rapid assessment of metal contamination in commercial fruit juices by inductively coupled mass spectrometry after a simple dilution, Journal of Food Composition and Analysis, 24 (2011) 95 - 102.

[21] F. Demir, A.S. Kipcak, O.D. Ozdemir, E.M. Derun, S. Piskin, Determination and Comparison of Some Elements in Different Types of Orange Juices and Investigation of Health Effects, International Journal of Biological, Biomolecular, Agricultural, Food and Biotechnological Engineering, 9(5) (2015) 498 - 502.

[22] WHO. Toxicological Evaluation of Certain Food Additives and Contaminants, 33rd Meeting of the Joint FAO/WHO Expert Committee on Food Additives: Cambridge, United Kingdom, 1989.

[23] J.K. Tufuor, J.K. Bentum, D.K. Essumang, J.E. Koranteng-
Addo, Analysis of heavy metals in citrus juice from the Abura-Asebu-Kwamankese District, Ghana, Journal of Chemical and Pharmaceutical Research, 3(2) (2011) 397-402.

[24] Y. Kaymak, E. Adişen, M. Erhan, B. Çelík, M.A. Gürer, Zinc Levels in Patients with Acne Vulgaris, Journal of the Turkish Academy Dermatology, 1(3) (2007) 1 - 4.

[25] B.L. O'Dell, R.A. Sunde, Molydbenum. In: Handbook of nutritionally essential mineral elements: CRC, 1997.

[26] W.A. Simpkins, H. Louie, M. Wu, M. Harrison, D. Goldberg. Trace elements in Australian orange juice and other products, Food Chemistry, 71(4) (2000) 423 - 433.

[27] G.N. Schrauzer, Lithium: Occurrence, Dietary Intakes, Nutritional Essentiality, Journal of the American College of Nutrition, 21(1) (2002) 14-21.

[28] L.C. Browning, A.J. Cowieson, Interactive effect of vitamin $D$ and strontium on performanceand bone composition in broiler chickens, Animal Feed Science and Technology, 205 (2015) 107-115.

[29] J.H. Beattie, H.S. Peace, The influence of a low-boron diet and boron supplementation on bone, major mineral and sex steroid metabolism in postmenopausal women, British Journal of Nutrition, 69(03) (1993) 871 - 884.

[30] J.G. Penland, The importance of boron nutrition for brain and psychological function, Biological trace element research, 66(1) (1998) $299-317$.

[31] S. Bhattacharjee, Y. Zhao, J. M. Hill, F. Culicchia, T. P. A. Kruck, M. E. Percy, A. I. Pogue, J. R. Walton, W. J. Lukiw, Selective accumulation of aluminum in cerebral arteries in Alzheimer's disease (AD), Journal of Inorganic Biochemistry, 126 (2013) $35-37$.

[32] H. Abdolmohammad-Zadeh, G. Sadeghi, Combination of ionic liquid-based dispersive liquid-liquid microextraction with stopped-flow spectrofluorometry for the preconcentration and determination of aluminum in natural waters, fruit juice and food samples, Talanta, 81(3) (2010) $778-785$.

[33] R. Massey, D. Taylor, Aluminium in food and the environment: the proceedings of a symposium organised by the Environment and Food Chemistry Groups of the Industrial Division of the Royal Society of Chemistry, Royal Society of Chemistry, London, 1989.

[34] H. J. Gitelman, Aluminum and health: A critical review, CRC Press, New York, 1989.

[35] Pravilnik o količinama pesticide, metala I metaloida I drugih otrovnih supstancija, hemioterapeutika, anabolika I drugih supstancija koje se mogu nalaziti u namirnicama, SI. list SRJ, br. 5/92, 11/92 - ispr. i 32/2002.

[36] Brown ML. Present knowledge in nutrition: International Life Sciences Institute Press; 1990.

[37] Herber R, Stoeppler M. Arsenic. In: Trace element analysis in biological specimens: Elsevier Science; 1994.

[38] Uthus E, Poellot R. Effect of dietary pyridoxine on arsenic deprivation in rats. Trace elements 1991;10:339-347. 


\section{PRISUSTVO METALA U BISTRIM SOKOVIMA OD POMORANDŽE}

Saša R. Savić, Sanja M. Petrović, Jovana J. Stamenković, Živomir B. Petronijević

Tehnološki fakultet, Univerzitet u Nišu, Leskovac, Srbija

Voćni sok predstavlja proizvod koji se dobija mehaničkom preradom jedne ili više vrsta tehnološki zrelog, svežeg, ohlađenog ili zamrznutog voća, koje nije fermentisalo ali može da fermentiše, čiji ukus, boja i aroma moraju da budu karakteristični za vrstu voća od koga je voćni sok proizveden. Voćni sokovi su važni u ljudskoj ishrani jer sadrže različite hranljive sastojke, pre svega vitamine, minerale i ugljene hidrate. $\mathrm{U}$ ovom radu ispitivan je sadržaj $\mathrm{Ag}, \mathrm{Al}, \mathrm{B}, \mathrm{Ca}, \mathrm{Cd}, \mathrm{Co}, \mathrm{Cr}, \mathrm{Cu}, \mathrm{Fe}, \mathrm{K}, \mathrm{Li}, \mathrm{Mg}, \mathrm{Mn}$, $\mathrm{Na}, \mathrm{Ni}, \mathrm{Pb}, \mathrm{Sr}, \mathrm{Zn}, \mathrm{Si}, \mathrm{As}, \mathrm{P}$, Mo i Sb u uzorcima sokova pomorandže prisutnih na lokalnom tržištu u Leskovcu. Priprema uzoraka vršena je vlažnom digestijom. Koncentracije ispitivanih metala u rastvorima posle digestije određivane su primenom optičke emisione spektrometrije sa indukovano spregnutom plazmom (ICP-OES). $\mathrm{Na}$ osnovu dobijenih rezultata može se zaključiti da prisustvo kalijuma i fosfora u ispitivanim sokovima nije na zadovoljavajućem nivou. Sa druge strane, zbog prisustva arsena i molibdena veća upotreba bistrih sokova od pomorandže može dovesti do neželjenih posledica.
(ORIGINALNI NAUČNI RAD) UDC 663.81:549.08

Ključne reči: Minerali, Bistri sokovi od pomorandže, ICP-OES 